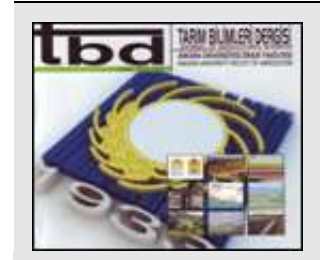

Tarım Bilimleri Dergisi

Journal of Agricultural Sciences

Tar. Bil. Der.

Dergi web sayfası:

www.agri.ankara.edu.tr/dergi

Journal homepage:

www.agri.ankara.edu.tr/journal

\title{
Combining Abilities and Heterotic Groups for Seed Yield and Yield Components in Pea (Pisum sativum L.)
}

\author{
Dilyaver Sinay HALIL ${ }^{a}$, Ayşen UZUNª \\ ${ }^{a}$ Department of Field Crops, Faculty of Agriculture, Bursa Uludag University, 16059, Bursa, TURKEY
}

\author{
ARTICLE INFO \\ Research Article \\ Corresponding Author: Ayşen UZUN, E-mail: uzunay@uludag.edu.tr, Tel: +90 (224) 2941520 \\ Received: 03 May 2019, Received in Revised Form: 03 July 2019, Accepted: 15 July 2019
}

AUTHORS ORCID ID:

(Dilyaver Sinay HALIL: 0000-0002-4532-1241 ), (Ayşen UZUN: 0000-0001-6043-8854 )

\begin{abstract}
The aim of this study was to investigate the combining ability and hybrid performance for seed yield and yield components in pea (Pisum sativum L.) genotypes. Field experiments were carried out in 2016-2017 during the winter growth period at Bursa Uludag University,Faculty of Agriculture,Agricultural Research and Application Center in Bursa, Turkey. In the study, four female (Debrecen3, Sel 3-25, USA5, and Vesela) and five male (Ardahan, Gap Pembesi, Kirazli, Milwa, and USA1) pea genotypes were used as parents. The all plants were planted on November 8, 2016. The experiment was carried out in the randomized complete block design
\end{abstract}

with three replications. Plant height $(\mathrm{cm})$, pods per plant (number), seeds per pod (number), seeds per plant (number), seed yield ( $g$ plant $\left.^{-1}\right)$, and 1000 -seed weight ( $\mathrm{g}$ ) of the plants were determined. In conclusion, the Sel 3-25, Ardahan, Gap pembesi, and Kirazli genotypes were decided to be suitable for use in future hybridization studies for seed yield due to high general combining ability. Also, Debrecen3xUSA1, Sel 3-25xGap pembesi, Sel 3-25xKirazli, USA5xArdahan, USA5xMilwa, and VeselaxKirazli hybrids were determined for seed yield as the best hybrid combinations due to high specific combining ability.

Keywords: Pea; Seed yield; Yield components; Combining ability; Heterotic groups

(C) Ankara Üniversitesi Ziraat Fakültesi

\section{Introduction}

Pea (Pisum sativum L.) is an important plant. Because it has high adaptability and seed yield, seeds and hay are used as animal fodder, seeds have excellent potential as a cheap source of high-quality protein (Kahraman et al 2015; Shaalan et al 2018). It is a good crop rotation plant and it can be used as green fertilizer plant (Uzun \& Acikgoz 1998). Number of the studies related to peas has increased because of pea's superior qualities. However, in order to improve the yield potential in forage pea, it is crucial to develop new genotypes. High genetic diversity in pea is important for success in the development of a new cultivar. The genetic variation among pea cultivars is low due to the limited number of parent plants used in breeding programs and the narrow gene pool (Espósito et al 2007; Şimşek \& Ceyhan 2017). In selfpollinated plants like pea, hybridization is one of the applications used to increase genetic variation (Askandar et al 2018). It is very important to selection suitable female and male parents to development of high yielding genotypes. Combining ability analysis provides is a substantial way of selecting superior parents in plant breeding (Bisht \& Singh 2011; Kosev 2013; Kumar et al 2017; Kafadar et al 2019). In general, high-quality cultivars are obtained from parents with high combining ability. Studies of combining ability, such as general combining ability and specific combining ability, are used to determine the hybrid performance of parent lines (Kosev 2013; Ceyhan et al 2014). The general combining ability is related to the additive effects of genes, while the specific combining ability is related to the dominance effects of genes 
(Sarode et al 2009; Ceyhan \& Kahraman 2013). The general combining ability of the parent plants helps developing genotypes with superior characteristics, while the specific combining ability gives information about the performance of the hybrid combinations (Cruz \& Regazzi 1994; Maarouf 2009; Sarode et al 2009). Heterosis, is the basis of hybrid breeding. In hybrid breeding, superior hybrids are selected by investigating their hybrid vigour. Heterosis and heterobeltiosis are of great importance in establishing the hybrid progenies (Yadav et al 2015). Heterosis is the superiority of the hybrid (F1) over its parents in terms of a certain trait. Heterobeltiosis is the superiority of the hybrid progeny over the superior parent. In self-pollinating plants like pea, hybridization is difficult and the use of heterosis in this plants is quite limited. Nevertheless, heterosis is used to determine the superiority of the hybrid progenies in a new variety (Rebika 2017). The Line $x$ Tester analysis is one of the methods used in the determination of the general and specific combining abilities and hybrid vigor (Ceyhan \& Avci 2005; Rashid et al 2007). In this method, the parents used as female are called lines and the parents-used as male are called testers. This method gives information about the effects of general and specific combining abilities and the genetic mechanism controlling the seed yield and some other traits (Espósito et al 2013; Mishra et al 2014). In the method, line and tester are crossed in all combinations. The combining ability with heterosis and heterobeltiosis values for seed yield and yield characteristics in pea has been reported by many previous research (Zaman \& Hazarika 2005; Kosev et al 2012; Kosev 2014; Mishra et al 2014; Kosev \& Naydenova 2015; Joshi et al 2015; Askandar et al 2018). In their studies on pea, Bisht \& Singh (2011), Kosev (2013), and Rebica et al (2013) stated that general combining ability was important in seed yield and yield characteristics. Borah (2009) and Kumar et al (2017) found that some pea hybrids had significant specific combining ability effects for yield and yield characteristics. Sarawat et al (1994), Ceyhan \& Avci (2005), and Rebika (2017) also determined significant values, which is positive or negative, for heterosis and heterobeltiosis in pea.

The aim of this study was to determine the amount of heterosis in twenty hybrids obtained from four line and five tester genotypes and to select parents and crosses having good combining abilities.

\section{Material and Methods}

The study was carried out in the experimental fields of the Bursa Uludag University, Faculty of Agriculture, Department of Field Crops in Bursa, Turkey $\left(40^{\circ} 11^{\prime}\right.$ North, 29 $04^{\prime}$ East) during the 2016-2017 growing season. During the growing period (November-July) total precipitation was $461.00 \mathrm{~mm}$; average temperature was $12.23{ }^{\circ} \mathrm{C}$; relative humidity was $71.78 \%$. The average long-term total precipitation during the plant growth period was $581.7 \mathrm{~mm}$; the mean temperature was $13.0^{\circ} \mathrm{C}$, and the relative humidity was $69.6 \%$. The study soil was clay-loam, non-saline, lime-poor, and had neutral reactive, very low in organic matter content, and sufficient amounts of available potassium and phosphorus.

In the experiment, four female (Debrecen3, Sel 3-25, USA5, and Vesela) and five male (Ardahan, Gap Pembesi, Kirazli, Milwa, and USA1) field pea genotypes were used. All female genotypes were leafed and white flowers. Origins of Debrecen3, Sel 3-25, USA5 and Vesela were Hungary, Turkey, USA and Bulgarian, respectively. Among Turkey origin male genotypes, Ardahan and Gap pembesi were leafed and purple flowers, while Kirazli was semi-leafless and had purple flower. The flower color of the Milwa, Poland origin, and USA1, USA origin, genotypes were pink. The Milwa was semi-leafless and USA1 was leafed. The hybridizations were carried out in 2013-2015 according to the Line $\mathrm{X}$ Tester method in the greenhouse and field conditions. The parents and the F1 hybrids were sown by hand on 8 November 2016. The experimental design was a randomized complete block with three replications. There were fourrows in a plot. The row length was $2 \mathrm{~m}$ while row to row was $70 \mathrm{~cm}$ and plant to plant $50 \mathrm{~cm}$. Before seeding, $30 \mathrm{~kg} N$ $\mathrm{ha}^{-1}$ fertilizer was applied as fertilizer. Weeds were controlled by hand four times. No irrigation was applied during the growing season. A herbicide (cypermethrin) was applied twice against Bruchus at the time of flowering. The plant height $(\mathrm{cm})$, pods per plant, seeds per pod, seeds per plant, seed yield per plant $(\mathrm{g})$ and 1000 seed weight $(\mathrm{g})$ were determined for all plants at harvest time. For the data obtained with the experiment, a variance analysis was performed according to the randomized block design and the JUMP package program was used for the analysis. The $1 \%$ and $5 \%$ probability levels were used in the significance tests. The least significant difference (LSD) was calculated at the 5\% probability level. The statistically-different groups were determined using the LSD test. The combining ability analysis was carried out as suggested by Singh \& Chaudhary (1977). For this purpose, the data was analyzed using the TARPOPGEN package program. The significance of heterosis and heterobeltiosis values of hybrids were determined at 0.05 and 0.01 levels using t test. 


\section{Results and Discussion}

In the study, the plant height $(\mathrm{cm})$, pods per plant, seeds per pod, seeds per plant, seed yield per plant $(\mathrm{g})$ and 1000 seed weight $(\mathrm{g})$ of the parents and hybrids were determined. In addition, combining ability and heterosis values of the genotypes were established. The variance analysis results (mean square) of plant height, pods per plant, seeds per pod, seeds per plant, seed yield per plant and 1000 seed weight are given in Table 1. As seen in the Table 1, the plant height, pods per plant, seeds per pod, seeds per plant, seed yield per plant and 1000 seed weight values of the genotypes were significant at the $1 \%$ level. All traits of the parent genotypes were significant at the $1 \%$ probability level. The 1000 seed weight of the parents versus crosses were significant at the $5 \%$ level, while the plant height, pods per plant, seeds per pod, seeds per plant and seed yield per plant values were significant at the $1 \%$ level. The crosses were significant at the $1 \%$ probability level for all characteristics. The difference between the lines was significant at the 5\% probability level only for 1000 seed weight values. The plant height, pods per plant, seeds per plant and 1000 seed weight of the testers were significant at the $1 \%$ probability level. The line $\mathrm{x}$ testers were statistically significant $1 \%$ probability level for all characteristics. The mean values of the plant height, pods per plant, seeds per pod, seeds per plant, seed yield per plant and 1000 seed weight for the crosses and parent plants are shown in Table 2. The mean values of the crosses were higher than the mean values of the parent genotypes for all characteristics. Similar results were also obtained in previous studies (Ceyhan \& Avci 2005; Ceyhan et al 2008; Ceyhan \& Kahraman 2013; Mishra et al 2014; Kumar et al 2017; Şimşek \& Ceyhan 2017; Shaalan et al 2018). The VeselaxUSA1 and Sel 3-25xArdahan crosses had the highest plant height. The highest number of pods per plant was obtained from the Sel 3-25xUSA1 and Debrecen3xArdahan crosses. The maximum number of seeds per pod was determined from the Debrecen3 line. The Sel 3-25xUSA1 cross had the highest seeds per plant value. The highest seeds per plant was obtained from the Vesela line and Sel 3-25xGap pembesi and Sel 3-25xKirazli crosses. The 1000 seed weight of USA5xUSA1 cross was the highest. The general combining and specific combining ability related to seed yield and seed yield components in pea are given Table 3. The Debrecen3 line had positive significant general combining ability effect for the number of seeds per pod. Female parent the Sel 3-25 line gave significant positive general combining ability effect for pods per plant, seeds per plant, seed yield per plant and 1000 seed weight. The USA5 genotype had a significantly positive general combining ability effect for 1000 seed weight. Significant general combining effect for plant height and pods per plant were obtained from the Vesela line. The Ardahan tester showed positive significant general combining ability effect for plant height, pods per plant, seeds per plant and seed yield per plant characteristics. Male parent the Gap pembesi had positive significant general combining ability effect for plant height, seed yield per plant and 1000 seed weight. The Kirazli tester showed positive significant general combining ability effect for plant height and seed yield per plant. Positive significant general combining effect for 1000 seed weight were determined from Milwa genotype. Male parent the USA1 tester gave significant positive general combining ability effect for pods per plant, seeds per plant and 1000 seed weight (Table 3). In this study, at least one parent genotype had a significantly positive general combining ability effect for all characteristics. The parent genotypes with a significantly positive general combining ability effect contribute to the increase in the investigated characteristics in hybridization studies. A significant general combining ability indicate the importance of additive gene effects. Ceyhan \& Avci (2005), Zaman \& Hazarika (2005), Ceyhan et al (2008), Bisht \& Singh (2011), Kosev (2013), and Rebica et al (2013) reported that the parent genotypes had significant general combining ability for above traits. Positive and significant specific combining effects were Debrecen3xArdahan, Sel 3-25xArdahan, USA5xGap pembesi, USA5xKirazli, VeselaxMliwa and VeselaxUSA1 hybrids for plant height. The Debrecen3xArdahan, Sel 3-25xUSA1, USA5xGap pembesi, USA5xKirazli and USA5xMilwa hybrids showed positive significant specific combining ability effect for pods per plant. The VeselaxArdahan hybrid for seeds per pod; Debrecen3xArdahan, Sel 3-25xUSA1, USA5xArdahan, USA5xGap pembesi, USA5xMilwa, VeselaxKirazli and VeselaxUSA1 hybrids for seeds per plant; Debrecen3xUSA1, Sel 3-25xGap Pembesi, Sel 3-25xKirazli, USA5xArdahan, USA5xMilwa and VeselaxKirazli hybrids for seed yield per plant; Sel 3-25xGap Pembesi, Sel 3-25xKirazli, Sel 3-25xMilwa, USA5xUSA1, VeselaxArdahan and VeselaxKirazli hybrids for 1000 seed weight had positive and significant specific combining effect (Table 3). Significant special combining ability explain that non-additive effects (dominant or epistatic) are important in the inheritance of investigated characters. Significant specific combining ability effects of hybrids is very important in selecting the cross. In previous studies with pea, significant specific combining ability effects have determined (Borah 2009; Kosev 2013; Mishra et al 2014; Kumar et al 2017). The heterosis and heterobeltiosis values with respect to the plant length, pods per plant, seeds per pod, seeds per plant, grain yield, and 1000-grain weight values of the hybrids are shown in Table 4. The heterosis values varied between -9.9 and $135.4 \%$ and the heterobeltiosis values varied between -28.1 and $82.7 \%$ for plant height. Both the heterosis and heterobeltiosis values of the plant height trait of the Debrecen3xArdahan, Sel 3-25xArdahan and USA5xArdahan hybrids were positive and statistically significant. In the study, heterosis values ranged from -41.8 to $331.0 \%$ and heterobeltiosis values ranged from -58.0 to $173.8 \%$ for pods per plant. The Debrecen3xArdahan, Sel 3-25xArdahan, Sel 3-25xUSA1,

Journal of Agricultural Sciences (Tarım Bilimleri Dergisi) 26 (2020) 415-423 
USA5xArdahan, VeselaxArdahan, and VeselaxUSA1 hybrids had positive significant heterosis and heterobeltiosis values for pods per plant. The heterosis and heterobeltiosis values of all hybrids were not statistically significant for seeds per pod. Positive and significant heterosis and heterobeltiosis values were observed for Debrecen3x Ardahan, Sel 325xArdahan, Sel 3-25xGap pembesi, Sel 3-25xUSA1, USA5xArdahan, VeselaxArdahan, and VeselaxUSA1 hybrids in seeds per plant. For this trait, the heterosis values varied between -33.5 and $664.7 \%$ and the heterobeltiosis values varied between -45.7 and $251.7 \%$. The heterosis and heterobeltiosis values ranged between -70.3 and $194.3 \%$ and -79.9 and $178.3 \%$ for seed yield per plant, respectively. The heterosis (194.3\%) and heterobeltiosis (178.3\%) values of Sel 3-25 x Kirazli hybrid and only heterosis $(135.8 \%)$ value of the Sel 3-25xGap pembesi hybrid were positive and statistically significant for seed yield per plant. Generally, hybrids with positive specific combining ability have given positive heterosis and heterobeltiosis values in this study. Sel 3-25xArdahan hybrid had negative and significant $(-36.5 \%)$ and USA5xUSA1 hybrid had positive and significant (32.9\%) heterosis values for 1000 seed weight. Negative and significant heterobeltiosis values were observed for USA5xKirazli $(-22.8 \%)$ and VeselaxArdahan $(-35.4 \%)$ hybrids in 1000 seed weight (Table 4). Hybrids that have significant and positive or negative specific combining ability and heterosis and heterobeltiosis values are expected to show a high variability in the investigated traits in the following generations. In future selection studies, the use of hybrid populations with a wide genetic variability will lead to faster genetic improvement and successful results. In their studies on peas, Sarawat et al (1994), Ceyhan \& Avci (2005), Ceyhan et al (2008), Joshi et al (2015), and Rebika (2017) determined positively and negatively significant heterosis and heterobeltiosis values for seed yield and yield components.

Table 1- Analysis of variance for Line $x$ tester in pea (mean squares)

\begin{tabular}{|c|c|c|c|c|c|c|c|}
\hline $\begin{array}{l}\text { Source of } \\
\text { variation }\end{array}$ & $\begin{array}{l}\text { Degre } \\
\text { of } \\
\text { freedom }\end{array}$ & $\begin{array}{l}\text { Plant } \\
\text { height }(\mathrm{cm})\end{array}$ & $\begin{array}{l}\text { Pods per } \\
\text { plant (no.) }\end{array}$ & $\begin{array}{l}\text { Seeds per } \\
\text { pod (no.) }\end{array}$ & $\begin{array}{l}\text { Seeds per } \\
\text { plant (no.) }\end{array}$ & $\begin{array}{l}\text { Seed yield } \\
\text { per plant }(g)\end{array}$ & $\begin{array}{l}1000 \text { seed } \\
\text { weight }(g)\end{array}$ \\
\hline Replications & 2 & $148.2767^{* * *}$ & $25.3134^{\mathrm{ns}}$ & $0.4445^{\mathrm{ns}}$ & $1401.1351^{\mathrm{ns}}$ & $16.9657^{\mathrm{ns}}$ & $23.0445^{\mathrm{ns}}$ \\
\hline Genotypes & 28 & $4875.9222 * *$ & $7336.9817 * *$ & $1.7530^{* *}$ & $99742.3378 * *$ & $1394.4133 * *$ & $10289.0805^{* *}$ \\
\hline Parents & 8 & $4164.1053 * *$ & $2039.0312 * *$ & $2.7224 * *$ & $16546.3490 * *$ & $1624.0960 * *$ & $11184.4031 * *$ \\
\hline Parents vs crosses & 1 & $22951.2618 * *$ & $21273.1139 * *$ & $8.1791 * *$ & $473890.3562 * *$ & $1117.1174 * *$ & $295.1376 *$ \\
\hline Crosses & 19 & $4224.3010 * *$ & $8834.2171 * *$ & $1.0066^{* *}$ & $115080.2269 * *$ & $1312.2994 * *$ & $10438.0995^{* *}$ \\
\hline Lines & 3 & $3045.2586^{\mathrm{ns}}$ & $5365.2798^{\mathrm{ns}}$ & $1.4961^{\mathrm{ns}}$ & $61172.6218^{\mathrm{ns}}$ & $2220.5307^{\mathrm{ns}}$ & $9543.7372 *$ \\
\hline Testers & 4 & $12133.1972 * *$ & $30027.9021^{* *}$ & $0.7317^{\mathrm{ns}}$ & $344914.7057 * *$ & $952.5595^{\mathrm{ns}}$ & $34696.5091 * *$ \\
\hline Line $\mathrm{x}$ Testers & 12 & $1882.7628 * *$ & $2636.8898 * *$ & $0.9758 * *$ & $51945.6532 * *$ & $1205.1548 * *$ & $2575.5535 * *$ \\
\hline Error & 56 & 28.4234 & 35.1313 & 0.3021 & 533.4480 & 54.1769 & 57.5032 \\
\hline
\end{tabular}

ns, non significant; *, significant at $\mathrm{P}=0.05$ probability level; **, significant at $\mathrm{P}=0.01$ probability level 
Table 2- Means seed yield and seed yield components in pea

\begin{tabular}{|c|c|c|c|c|c|c|}
\hline Parents & $\begin{array}{l}\text { Plant } \\
\text { height } \\
(\mathrm{cm})\end{array}$ & $\begin{array}{l}\text { Pods per } \\
\text { plant } \\
\text { (no.) }\end{array}$ & $\begin{array}{l}\text { Seeds per } \\
\text { pod } \\
\text { (no.) }\end{array}$ & $\begin{array}{l}\text { Seeds per } \\
\text { plant } \\
\text { (no.) }\end{array}$ & $\begin{array}{l}\text { Seed yield per } \\
\text { plant } \\
(\mathrm{g})\end{array}$ & $\begin{array}{l}1000 \text { seed } \\
\text { weight } \\
(\mathrm{g})\end{array}$ \\
\hline \multicolumn{7}{|l|}{ Lines } \\
\hline Debrecen 3 & $41.83 \mathrm{r}$ & $13.50 \mathrm{q}$ & $7.88 \mathrm{a}$ & $75.25 \mathrm{o}$ & $18.82 \mathrm{n}$ & $138.87 \mathrm{~m}$ \\
\hline Sel 3-25 & $50.32 \mathrm{qr}$ & $17.32 \mathrm{pq}$ & $5.49 \mathrm{i}-\mathrm{k}$ & $141.50 \mathrm{mn}$ & $30.51 \mathrm{k}-\mathrm{n}$ & $231.25 \mathrm{e}$ \\
\hline USA5 & $46.13 \mathrm{r}$ & $15.88 \mathrm{q}$ & $6.75 \mathrm{~b}-\mathrm{h}$ & $80.23 \mathrm{o}$ & $43.87 \mathrm{f}-\mathrm{j}$ & $255.03 \mathrm{~cd}$ \\
\hline Vesela & $139.00 \mathrm{ef}$ & $62.11 \mathrm{gh}$ & $5.00 \mathrm{k}$ & $242.09 \mathrm{~h}-\mathrm{j}$ & $99.34 \mathrm{a}$ & 155.471 \\
\hline \multicolumn{7}{|l|}{ Tester } \\
\hline Ardahan & 91.251 & $87.50 \mathrm{~d}$ & $6.00 \mathrm{~h}-\mathrm{j}$ & $306.50 \mathrm{~g}$ & $59.45 \mathrm{c}-\mathrm{e}$ & $68.15 \mathrm{p}$ \\
\hline Gap pembesi & $117.79 \mathrm{ij}$ & $61.67 \mathrm{gh}$ & $6.27 \mathrm{f}-\mathrm{i}$ & $192.63 \mathrm{kl}$ & $49.27 \mathrm{e}-\mathrm{i}$ & 221.27 ef \\
\hline Kirazli & $129.00 \mathrm{gh}$ & $49.17 \mathrm{i}-\mathrm{k}$ & $6.50 \mathrm{c}-\mathrm{h}$ & $158.331-n$ & $34.24 \mathrm{jk}$ & $180.03 \mathrm{k}$ \\
\hline Milwa & 62.33 op & $37.50 \mathrm{~lm}$ & $4.72 \mathrm{k}$ & $153.33 \mathrm{mn}$ & $37.89 \mathrm{~h}-\mathrm{k}$ & $252.10 \mathrm{~d}$ \\
\hline USA1 & $77.35 \mathrm{~m}$ & $64.00 \mathrm{fg}$ & $6.00 \mathrm{~h}-\mathrm{j}$ & $210.25 \mathrm{jk}$ & $35.53 \mathrm{jk}$ & $207.50 \mathrm{gh}$ \\
\hline \multicolumn{7}{|l|}{ Crosses } \\
\hline Debrecen3xArdahan & $149.50 \mathrm{~cd}$ & $173.83 \mathrm{a}$ & $6.33 \mathrm{e}-\mathrm{i}$ & $694.92 \mathrm{~b}$ & $55.92 \mathrm{c}-\mathrm{e}$ & 88.15 o \\
\hline Debrecen3xGap pembesi & $123.22 \mathrm{hi}$ & $35.171-n$ & $7.55 \mathrm{ab}$ & $237.11 \mathrm{ij}$ & $31.86 \mathrm{j}-\mathrm{m}$ & $204.17 \mathrm{hi}$ \\
\hline Debrecen3xKirazli & $108.15 \mathrm{k}$ & $21.70 \mathrm{o}-\mathrm{q}$ & $7.20 \mathrm{a}-\mathrm{e}$ & $123.35 \mathrm{n}$ & $32.38 \mathrm{j}-1$ & $176.87 \mathrm{k}$ \\
\hline Debrecen3xMilwa & 61.15 op & $29.31 \mathrm{~m}-\mathrm{o}$ & 7.18 a-e & $151.00 \mathrm{mn}$ & $31.94 \mathrm{j}-\mathrm{m}$ & $218.80 \mathrm{fg}$ \\
\hline Debrecen3xUSA1 & $75.00 \mathrm{mn}$ & $72.25 \mathrm{ef}$ & $7.33 \mathrm{a}-\mathrm{c}$ & $245.00 \mathrm{~h}-\mathrm{j}$ & $62.88 \mathrm{~cd}$ & $205.00 \mathrm{hi}$ \\
\hline Sel 3-25xArdahan & $166.67 \mathrm{a}$ & $158.67 \mathrm{~b}$ & $6.83 \mathrm{~b}-\mathrm{h}$ & $560.50 \mathrm{~cd}$ & $52.00 \mathrm{~d}-\mathrm{g}$ & $95.05 \mathrm{o}$ \\
\hline Sel 3-25xGap pembesi & $140.88 \mathrm{~d}-\mathrm{f}$ & $81.75 \mathrm{de}$ & $6.48 \mathrm{c}-\mathrm{h}$ & $362.63 \mathrm{f}$ & $94.06 \mathrm{a}$ & $243.98 \mathrm{~d}$ \\
\hline Sel 3-25xKirazli & $122.17 \mathrm{hi}$ & $56.73 \mathrm{~g}-\mathrm{j}$ & $6.38 \mathrm{~d}-\mathrm{i}$ & $269.66 \mathrm{~g}-\mathrm{i}$ & $95.29 \mathrm{a}$ & 228.75 ef \\
\hline Sel 3-25xMilwa & 67.38 no & $40.85 \mathrm{kl}$ & $7.34 \mathrm{a}-\mathrm{c}$ & $172.38 \mathrm{~lm}$ & $62.26 \mathrm{~cd}$ & $266.70 \mathrm{bc}$ \\
\hline Sel 3-25xUSA1 & 88.831 & $175.25 \mathrm{a}$ & $7.00 \mathrm{a}-\mathrm{g}$ & $739.50 \mathrm{a}$ & 49.88 e-h & 205.35 hi \\
\hline USA5xArdahan & $154.61 \mathrm{bc}$ & $134.17 \mathrm{c}$ & $6.75 \mathrm{~b}-\mathrm{h}$ & $576.25 \mathrm{c}$ & $75.29 \mathrm{~b}$ & $123.03 \mathrm{n}$ \\
\hline USA5xGap pembesi & $161.50 \mathrm{ab}$ & $48.50 \mathrm{jk}$ & $6.83 \mathrm{~b}-\mathrm{h}$ & $274.25 \mathrm{~g}-\mathrm{i}$ & $55.57 \mathrm{c}-\mathrm{f}$ & $206.30 \mathrm{~h}$ \\
\hline USA5xKirazli & $146.46 \mathrm{c}-\mathrm{e}$ & $40.09 \mathrm{kl}$ & $6.02 \mathrm{~h}-\mathrm{j}$ & $139.50 \mathrm{mn}$ & $37.46 \mathrm{i}-\mathrm{k}$ & $196.90 \mathrm{~h}-\mathrm{j}$ \\
\hline USA5xMilwa & $68.92 \mathrm{~m}-\mathrm{o}$ & $58.22 \mathrm{~g}-\mathrm{i}$ & $7.13 \mathrm{a}-\mathrm{f}$ & $275.00 \mathrm{gh}$ & $66.56 \mathrm{bc}$ & $275.05 \mathrm{~b}$ \\
\hline USA5xUSA1 & $55.63 \mathrm{pq}$ & $26.88 \mathrm{n}-\mathrm{p}$ & $6.42 \mathrm{~d}-\mathrm{h}$ & $142.88 \mathrm{mn}$ & $21.751-n$ & $307.57 \mathrm{a}$ \\
\hline VeselaxArdahan & $149.67 \mathrm{c}$ & $164.05 \mathrm{~b}$ & $7.25 \mathrm{a}-\mathrm{d}$ & $524.91 \mathrm{de}$ & $52.42 \mathrm{~d}-\mathrm{g}$ & $100.47 \mathrm{o}$ \\
\hline VeselaxGap pembesi & $135.00 \mathrm{fg}$ & $53.60 \mathrm{~h}-\mathrm{j}$ & $7.00 \mathrm{a}-\mathrm{g}$ & $289.83 \mathrm{~g}$ & $58.02 \mathrm{c}-\mathrm{e}$ & $193.15 \mathrm{ij}$ \\
\hline VeselaxKirazli & $126.33 \mathrm{~g}-\mathrm{i}$ & $58.00 \mathrm{~g}-\mathrm{j}$ & $6.25 \mathrm{f}-\mathrm{i}$ & 243.33 h-1 & $66.21 \mathrm{bc}$ & $188.15 \mathrm{jk}$ \\
\hline VeselaxMilwa & $110.88 \mathrm{jk}$ & $29.00 \mathrm{~m}-\mathrm{o}$ & $6.13 \mathrm{~g}-\mathrm{i}$ & $131.50 \mathrm{n}$ & 41.84 g-k & $198.78 \mathrm{~h}-\mathrm{j}$ \\
\hline VeselaxUSA1 & $168.00 \mathrm{a}$ & $126.25 \mathrm{c}$ & $5.17 \mathrm{jk}$ & $504.00 \mathrm{e}$ & $20.00 \mathrm{mn}$ & 156.701 \\
\hline
\end{tabular}


Table 3- General combining ability (GCA) and specific combining ability (SCA) related to seed yield and seed yield components in pea

\begin{tabular}{|c|c|c|c|c|c|c|}
\hline Parents & $\begin{array}{r}\text { Plant } \\
\text { height }(\mathrm{cm})\end{array}$ & $\begin{array}{c}\text { Pods per } \\
\text { plant(no.) }\end{array}$ & $\begin{array}{r}\text { Seeds perpod } \\
\text { (no.) }\end{array}$ & $\begin{array}{l}\text { Seeds per } \\
\text { plant (no.) }\end{array}$ & $\begin{array}{r}\text { Seed yield } \\
\text { per plant }(g)\end{array}$ & $\begin{array}{l}1000 \text { seed } \\
\text { weight }(g)\end{array}$ \\
\hline Lines & & & & & & GCA \\
\hline Debrecen3 & $-15.593 * *$ & $-12.781 * *$ & $0.389 * *$ & $-42.599 * *$ & $-10.185^{* *}$ & $-15.348 * *$ \\
\hline Sel 3-25 & -1.811 & $23.417 * *$ & 0.077 & $88.058 * *$ & $17.519 * *$ & $14.023^{* *}$ \\
\hline USA5 & -1.574 & $-17.663 * *$ & -0.102 & $-51.299 * *$ & -1.854 & $27.826 * *$ \\
\hline Vesela & $18.978^{* *}$ & $7.027 * *$ & $-0.364 *$ & 5.84 & $-5.481 * *$ & $-26.521 * *$ \\
\hline \multicolumn{7}{|l|}{ Tester } \\
\hline Ardahan & $36.113 * *$ & $78.447 * *$ & 0.062 & $256.271 * *$ & $5.727 * *$ & $-92.269 * *$ \\
\hline Gap pembesi & $21.154 * *$ & $-24.379 * *$ & 0.237 & $-41.92 * *$ & $6.699 * *$ & $17.956 * *$ \\
\hline Kirazli & $6.781 * *$ & $-35.104 * *$ & -0.269 & $-138.915 * *$ & $4.655^{*}$ & 3.723 \\
\hline Milwa & $-41.916^{* *}$ & $-39.888 * *$ & 0.221 & $-150.405 * *$ & -2.529 & $45.881 * *$ \\
\hline USA1 & $-22.132 * *$ & $20.924 * *$ & -0.251 & $74.97 * *$ & $-14.553 * *$ & $24.71 * *$ \\
\hline Crosses & & & & & & SCA \\
\hline Debrecen3xArdahan & $9.98 * *$ & $28.932 * *$ & $-0.85 * *$ & $148.371 * *$ & 7.195 & 1.823 \\
\hline Debrecen3xGap pembesi & -1.338 & $-6.905^{*}$ & 0.197 & -11.245 & $-17.836^{* *}$ & 7.614 \\
\hline Debrecen3xKirazli & -2.035 & $-9.648 * *$ & 0.35 & $-28.01 *$ & $-15.272 * *$ & -5.452 \\
\hline Debrecen3xMilwa & -0.335 & 2.746 & -0.163 & 11.13 & $-8.522 *$ & -5.677 \\
\hline Debrecen3xUSA1 & $-6.272 *$ & $-15.125^{* *}$ & 0.466 & $-120.245^{* *}$ & $34.435 * *$ & 1.693 \\
\hline Sel 3-25xArdahan & $13.368 * *$ & $-22.429 * *$ & -0.035 & $-116.703 * *$ & $-24.425^{* *}$ & $-20.648 * *$ \\
\hline Sel 3-25xGap pembesi & 2.543 & 3.48 & -0.561 & -16.385 & $16.664 * *$ & $18.061 * *$ \\
\hline Sel 3-25xKirazli & -1.797 & $-10.816^{* *}$ & -0.158 & -12.36 & $19.938 * *$ & $17.061 * *$ \\
\hline Sel 3-25xMilwa & $-7.893^{*}$ & $-21.912 * *$ & 0.309 & $-98.15 * *$ & -5.909 & $12.853 * *$ \\
\hline Sel 3-25xUSA1 & $-6.221^{*}$ & $51.677 * *$ & 0.444 & $243.598 * *$ & -6.268 & $-27.327 * *$ \\
\hline USA5xArdahan & 1.074 & -5.85 & 0.06 & $38.404 * *$ & $18.238 * *$ & -6.467 \\
\hline USA5xGap pembesi & $22.923 * *$ & $11.309 * *$ & -0.033 & $34.595^{*}$ & -2.457 & $-33.426 * *$ \\
\hline USA5xKirazli & $22.257 * *$ & $13.62 * *$ & -0.344 & -3.16 & $-18.523 * *$ & $-28.592 * *$ \\
\hline USA5xMilwa & $-6.59 *$ & $36.538 * *$ & 0.277 & $143.83 * *$ & $17.764 * *$ & 7.399 \\
\hline USA5xUSA1 & $-39.664 * *$ & $-55.617 * *$ & 0.039 & $-213.669 * *$ & $-15.022 * *$ & $61.087 * *$ \\
\hline VeselaxArdahan & $-24.421 * *$ & -0.653 & $0.825 *$ & $-70.072 * *$ & -1.009 & $25.293 * *$ \\
\hline VeselaxGap pembesi & $-24.129 * *$ & $-7.884 *$ & 0.396 & -6.964 & 3.63 & 7.751 \\
\hline VeselaxKirazli & $-18.425^{* *}$ & 6.844 & 0.152 & $43.531 * *$ & $13.857 * *$ & $16.984 * *$ \\
\hline VeselaxMilwa & $14.818 * *$ & $-17.372 * *$ & -0.424 & $-56.81 * *$ & -3.333 & $-14.574 * *$ \\
\hline VeselaxUSA1 & $52.157 * *$ & 19.066 & $-0.949 * *$ & $90.316 * *$ & $-13.145^{* *}$ & $-35.453^{* *}$ \\
\hline
\end{tabular}

*, significant at $\mathrm{p}=0.05$ probability level; $* *$, significant at $\mathrm{p}=0.01$ probability level 
Table 4- Heterosis $\left(\mathrm{H}_{\mathrm{s}}\right)(\%)$ and heterobeltiosis $\left(\mathrm{H}_{\mathrm{b}}\right)(\%)$ values of hybrids for seed yield and seed yield componenets in pea

\begin{tabular}{|c|c|c|c|c|c|c|c|c|c|c|c|c|}
\hline \multirow[t]{2}{*}{ Crosses } & \multicolumn{2}{|c|}{$\begin{array}{l}\text { Plant height } \\
(\mathrm{cm})\end{array}$} & \multicolumn{2}{|c|}{$\begin{array}{c}\text { Pods per plant } \\
\text { (no.) }\end{array}$} & \multicolumn{2}{|c|}{$\begin{array}{l}\text { Seeds per pod } \\
\text { (no.) }\end{array}$} & \multicolumn{2}{|c|}{$\begin{array}{l}\text { Seeds per plant } \\
\text { (no.) }\end{array}$} & \multicolumn{2}{|c|}{$\begin{array}{c}\text { Seed yield per plant } \\
(\mathrm{g})\end{array}$} & \multicolumn{2}{|c|}{$\begin{array}{c}1000 \text { seed weight } \\
(\mathrm{g})\end{array}$} \\
\hline & $H_{s}$ & $H_{b}$ & $H_{s}$ & $H_{b}$ & $H_{s}$ & $H_{b}$ & $H_{s}$ & $H_{b}$ & $H_{s}$ & $H_{b}$ & $H_{s}$ & $H_{b}$ \\
\hline DxA*** & $124.7 * *$ & $63.8 * *$ & $44.2 * *$ & $98.7 * *$ & -8.8 & -19.7 & $54.7 * *$ & $126.7^{* * *}$ & 42.9 & -5.9 & -14.8 & -36.5 \\
\hline DxGP & $54.4^{*}$ & 4.6 & -6.4 & -42.9 & 6.6 & -4.2 & 77.0 & 23.1 & -6.4 & -35.3 & 13.4 & -7.7 \\
\hline DxK & 26.6 & -16.2 & -30.8 & -55.9 & 0.1 & -8.6 & 5.6 & -22.1 & 22.1 & -5.4 & 10.9 & -1.8 \\
\hline DxM & 17.4 & -1.9 & 14.9 & -21.8 & 13.9 & -8.9 & 32.1 & -1.5 & 12.6 & -15.7 & 11.9 & -13.2 \\
\hline DxU1 & 25.9 & -3.1 & 86.5 & 12.9 & 5.6 & -6.9 & 71.6 & 16.5 & 131.4 & 76.9 & 18.4 & -1.2 \\
\hline SxA & $135.4 * *$ & $82.7 * *$ & $202.8 * *$ & $81.3 * *$ & 10.9 & 13.8 & $352.0 * *$ & $82.9 * *$ & 15.6 & -12.5 & $-36.5^{*}$ & -58.9 \\
\hline SxGP & $67.5 * *$ & 19.6 & $106.9^{*}$ & 32.6 & 10.2 & 3.4 & $117.0^{*}$ & $88.3^{*}$ & $135.8^{*}$ & 90.9 & 7.8 & 5.5 \\
\hline SxK & 36.3 & -5.3 & 70.6 & 15.4 & 6.3 & -1.9 & 79.9 & 70.3 & $194.3^{*}$ & $178.3^{*}$ & 11.2 & -1.1 \\
\hline SxM & 19.6 & 8.1 & 49.0 & 8.9 & 43.6 & 33.7 & 16.9 & 12.4 & 82.1 & 64.3 & 10.4 & 5.8 \\
\hline SxU1 & 39.1 & 14.8 & $331.0 * *$ & 173.8 ** & 21.7 & 16.7 & $320.5^{* *}$ & $251.7 * *$ & 51.2 & 40.4 & -6.4 & -11.2 \\
\hline U5xA & $125.1 * *$ & $69.4 * *$ & $159.6^{* * *}$ & $53.3^{*}$ & 5.8 & 0 & $198.0 * *$ & $88.0 * *$ & 45.7 & 26.6 & -23.9 & -51.8 \\
\hline U5xGP & $97.1 * *$ & $37.1 *$ & 25.1 & -21.4 & 4.9 & 1.2 & 101.0 & 42.4 & 19.3 & 12.8 & -13.4 & -19.1 \\
\hline U5xK & $67.3 * *$ & 13.5 & 23.2 & -18.5 & -9.2 & -10.8 & 16.9 & -11.9 & -4.1 & -14.6 & -9.5 & $-22.8^{*}$ \\
\hline U5xM & 27.1 & 10.6 & 118.1 & 55.3 & 24.2 & 5.6 & 135.5 & 79.4 & 62.8 & 51.7 & 8.5 & 7.9 \\
\hline U5xU1 & -9.9 & -28.1 & -32.7 & -58.0 & 0.6 & -4.9 & -1.6 & -32.0 & -45.2 & -50.4 & $32.9 * *$ & 20.6 \\
\hline VxA & 30.0 & 7.7 & $119.3^{* *}$ & $87.5^{* *}$ & 31.8 & 20.8 & $91.4 * *$ & $71.3 * *$ & -33.9 & -47.2 & -10.1 & $-35.4 *$ \\
\hline VxGP & 5.1 & -2.9 & -13.4 & -13.7 & 24.1 & 11.6 & 33.3 & 0.2 & -21.9 & -41.6 & 2.5 & -12.7 \\
\hline VxK & -5.7 & -9.1 & 4.2 & -6.6 & 8.7 & -3.9 & 21.5 & 0.5 & -0.9 & -33.4 & 12.2 & 4.5 \\
\hline VxM & 10.1 & -20.2 & -41.8 & -53.3 & 26.1 & 22.6 & -33.5 & -45.7 & -39.0 & $-57.9^{*}$ & -2.5 & -21.2 \\
\hline VxU1 & $55.3 * *$ & 20.9 & $100.2 * *$ & $97.3 * *$ & -6.0 & -13.8 & $120.8^{* *}$ & $108.2^{* *}$ & -70.3 & $-79.9 * *$ & -13.7 & -24.5 \\
\hline
\end{tabular}

***, DxA= Debrecen3xArdahan; DxGP= Debrecen3xGap pembesi; DxK= Debrecen3xKirazli; DxM= Debrecen3xMilwa; DxU1=Debrecen3xUSA1; SxA=Sel 3-25xArdahan; SxGP=Sel 3-25xGap pembesi; SxK=Sel 3-25xKirazli; SxM=Sel 3-25xMilwa; SxU1=Sel 3-25xUSA1; U5xA= USA5xArdahan; U5xGP= USA5xGap pembesi; U5xK=USA5xKirazli; U5xM=USA5xMilwa; U5xU1=USA5xUSA1; VxA=VeselaxArdahan; VxGP=VeselaxGap pembesi; VxK=VeselaxKirazli; VxM=VeselaxMilwa; VxU1=VeselaxUSA1; *, significant at $\mathrm{p}=0.05$ probability level; **, significant at $\mathrm{p}=0.01$ probability level

\section{Conclusions}

As a result, Sel 3-25, Ardahan, Gap pembesi, and Kirazli parents had significant general combining ability and these parents should be used in future hybridization studies. In addition, Debrecen3xUSA1, Sel 3-25xGap pembesi, Sel 325xKirazli, USA5xArdahan, USA5xMilwa, and VeselaxKirazli hybrids which have significant general combining ability and heterosis values might be considered promising for future breeding studies.

\section{Acknowledgements}

This study is a part of the PhD thesis "Determination of Combining Ability and Agricultural Characteristics of Some Pea (Pisum sativum L.) Hybrids" conducted at Bursa Uludag University, Natural and Applied Science Institute.

\section{References}

Askandar H S, Zibari P A A \& Teli Z A (2018). Heterosis, combining ability and gene action estimatio in pea (Pisum sativa L.) using full diallel crosses. Iraqi Journal of Agricultural Sciences 49(4): 969-976

Bisht B \& Sing Y V (2011). Combining ability for yield and yield contributing characters in pea (Pisum sativum L.). Journal of Vegetation Science 38(1): 17-21

Borah H K (2009). Studies on combining ability and heterosis in field pea (Pisum sativum L.). Legume Research 32(4): 255-259 
Ceyhan E \& Avc1 M A (2005). Combining bility and heterosis for grain yield and some yield components in Pea (Pisum sativum L.). Pakistan Journal of Biological Sciences 8(10): 1447-1452

Ceyhan E \& Kahraman A (2013). Genetic Analysis of yield and some characters in peas. Legume Research 36(4): 273-279

Ceyhan E, Avcı M A \& Karadas S (2008). Line X tester analysis in pea (Pisum sativum L.): Identification of superior parents for seed yield and its components. African Journal of Biology 7(16): 2810-2817

Ceyhan E, Harmankaya M \& Kahraman A (2014). Combining ability and heterosis for concentration of mineral elements and protein in common bean (Phaseolus vulgaris L). Turklsh Journal of Agriculture and Forestry 38(5): 581-590

Cruz C D \& Regazzi A J (1994). Models of biometrics applied for genetic improvement. Federal University of Vicosa Press, Vicosa, MG, Brazil, $390 \mathrm{p}$

Espósito M A, Martin E A, Cravero V P \& Cointry E L (2007). Characterization of pea accessions by SRAP's markers. Scientia Horticulturae 113: 329-335

Espósito M A, Gatti I, Cravero V P, Anido F S L \& Cointry E L (2013). Combining abilities and heterotic groups in Pisum sativum L. Australian Journal of Crop Science 7(11): 1634-1641

Joshi D J, Ravindrababu Y, Patel A M \& Chauhan S S (2015). Heterosis studies for grain yield and it's contributing traits in field pea (Pisum sativum L. var. arvense). Asian Journal of Biological Sciences 10(2): 158-161

Kafadar F N, Özkan A, Can C, Kar Y, Mart D \& Ceyhan E (2019). Genetic and biochemical properties of Cicer spp reveal distinction between wild and cultivated chickpea genotypes. Legume Research-An Internatıonal Journal 42(1): 1-9

Kosev V (2013). A brief study on the combining abilities of quantitative traits in field pea (Pisum sativum L.). Pinnacle Biosciences 2013: $1-5$

Kosev V (2014). Breeding potential of the field pea (Pisum sativum L.) cultivars and their progenies. Journal of Bioscience and Biotechnology 3(3): 219-226

Kosev V \& Naydenova Y (2015). Heritability of qualitative traits in forage pea (Pisum sativum L.). OnLine Journal of Biological Sciences 15(4): 274-281

Kosev V, Pachev I, Angelova S \& Mikic A (2012). Inheritance of quantitative traits in crosses between two Pisum sativum subspecies with particular reference to their breeding value. Russian Journal of Genetics 48(1): 41-46

Kahraman A, Ceyhan E \& Harmankaya M (2015). Nutritional variation and drought tolerance in chickpeas (Cicer arietinum L). Journal of Elementology 19(2): 331-341

Kumar M, Jeberson M S, Sing N B \& Sharma R (2017). Genetic analysis of seed yield and its contributing traits and pattern of their inheritance in field pea (Pisum sativum L.). International Journal of Current Microbiology and Applied Sciences 6(6): 172-181

Maarouf M (2009). Linextester analysis acress locations and years in Sudanesexexotic lines of forage sorghum. Journal of Plant Breeding and Crop Science 1(9): 311-319

Mishra V D, Sing H, Singh P K, Lal G M, Prasad R D \& Singh S K (2014). Study on combining ability effects for seed yield and its component characters in field pea (Pisum sativum L.). Annals AgriBio Research 9(4): 728-732

Rashid M, Cheema A A \& Ashraf M (2007). Line x tester analysis in basmati rice. Pakistan Journal of Botany 39(6): 2035-2042

Rebika T (2017). Heterosis study for yield and yield components in pea (Pisum sativum L.). International Journal of Current Microbiology and Applied Sciences 6(8): 45-50

Rebica T, Kumar M, Sharma P R, Noren K S \& Datt S (2013). Combining ability analysis for seed yield and component traits in pea under foot hills of northeast India. Sabrao Journal of Breeding and Genetics 45(2): 276-282

Sarawat P, Stoddard F L, Marshall D R \& Ali S M (1994). Heterosis for yield and related characters in pea. Euphytica 80: 39-48 
Sarode S B, Guptaand K \& Srivastava C P (2009). Line x Tester analysis in pea (Pisum sativum L.). International Journal of Plant Sciences 4(1): 233-236

Shaalan M A A, Sliman A S, El-Sayed S F, Amira Sh Soliman \& Mohamed S A (2018). Studies on gene effects and combining ability for some characteristics of pea (Pisum sativum) new linesin Egypt. Bioscience Research 15(4): 4417-4432

Singh R B \& Chaudhary B D (1977). Biometrical methods in quantitative genetic analysis.10: Line x tester analysis, Kalyani Publishers, New Delhi

Şimşek D \& Ceyhan E (2017). Inheritance of some agronomic characters in pea. Tarim Bilimleri Dergisi-Journal of Agricultural Sciences 23(1): 34-41

Uzun A \& Acikgoz E (1998). Effect of sowing season and seeding rate on the morphological traits and yields in pea cultivars of differing leaf types. Journal of Agronomy and Crop Science 181: 215-222

Yadav S K, Nanda H C, Nair S K, Gandley T \& Sao M (2015). Heterosis studies for yield and quality attributes in field pea (Pisum sativum L.). Progressive Research-An International Journal 10 (Special VII): 3845-3848

Zaman S \& Hazarika G N (2005). Combining ability in pea (Pisum sativum L.). Legume Research 28(4): 300-302 